\title{
Temporal expression of estrogen receptor $\alpha$ in the hypothalamus and medulla oblongata during fasting: a role of noradrenergic neurons
}

\author{
Beverly A S Reyes $^{1,2}$, Hiroko Tsukamura ${ }^{1}$, Helen I'Anson ${ }^{3}$, Maria Amelita C Estacio' ${ }^{1}$, Kanjun Hirunagi ${ }^{1}$ \\ and Kei-Ichiro Maeda ${ }^{1}$ \\ ${ }^{1}$ Graduate School of Bioagricultural Sciences, Nagoya University, Nagoya 464-8601, Japan \\ ${ }^{2}$ Department of Neurosurgery, Farber Institute for Neurosciences, Thomas Jefferson University, 900 Walnut Street, Suite 400, Philadelphia, \\ Pennsylvania 19107, USA \\ ${ }^{3}$ Department of Biology, Washington and Lee University, Lexington, Virginia 24450-03, USA \\ (Requests for offprints should be addressed to B A S Reyes; Email: bsr103@jefferson.edu)
}

\begin{abstract}
Fasting-induced LH suppression is augmented by estrogen in female rats. We investigated the temporal changes in the number of estrogen receptor $\alpha(E R \alpha)$-immunoreactive (ir) cells in various brain regions in ovariectomized rats fasted for $6,24,30$, and $48 \mathrm{~h}$, commencing at $1300 \mathrm{~h}$. We also determined the anatomical relationship of ER $\alpha$ immunoreactivity and dopamine- $\beta$-hydroxylase (DBH) neurons in the A2 region of the nucleus of the solitary tract (NTS) and the paraventricular nucleus (PVN). The number of ER $\alpha$-ir cells significantly increased after $30 \mathrm{~h}$ from the onset of fasting in the PVN and NTS compared with the unfasted controls and was sustained until $48 \mathrm{~h}$. In the A2 region of 48 -h fasted rats, $46 \cdot 75 \%$ DBH-ir cells expressed ER $\alpha$,
\end{abstract}

and this was significantly higher than in unfasted controls $(8 \cdot 16 \%$ DBH-ir cells expressed ER $\alpha)$. In the PVN, most $E R \alpha$-ir neurons were juxtaposed with $\mathrm{DBH}$-ir varicosities. These results suggest that $E R \alpha$ is expressed in specific brain regions at a defined time from the onset of fasting. In addition, the anatomical relationship of noradrenergic and $\mathrm{ER} \alpha$-ir neurons in the A2 region and PVN may suggest a role for estrogen in increasing the activity of noradrenergic neurons in the A2 region and enhancing sensitivity of the PVN to noradrenergic input arising from the lower brainstem and thereby augmenting the suppression of $\mathrm{LH}$ secretion during fasting.

Journal of Endocrinology (2006) 190, 593-600

\section{Introduction}

Among the environmental factors that control mammalian reproduction, food availability plays a vital role and probably acts as a proximate regulator of reproductive performance (Bronson 1989). Indeed, repeated investigations have shown that 48-h fasting dramatically suppresses pulsatile luteinizing hormone $(\mathrm{LH})$ secretion in female rats, and the suppression is largely dependent on the estrogenic milieu (Cagampang et al. 1991, Maeda et al. 1996). As such, 48-h fasting suppressed LH secretion only in intact and estradiol-treated rats but not in ovariectomized (OVX) rats (Cagampang et al. 1991, Maeda et al. 1996). Estrogen is also essential in modulating reproductive functions during seasonal shifts in reproductive activity (Goodman et al. 1981).

Several lines of evidence suggest a significant role for estrogen receptor (ER) in mediating reproductive events during energy-deficient conditions. In OVX Syrian hamsters, food deprivation decreases the number of ER-immunoreactive (ER-ir) cells in the ventromedial hypothalamus $(\mathrm{VMH})$ and area lateral to it, and increases the number of ER-ir cells in the medial preoptic area (mPOA; Li et al. 1994) and parvocellular paraventricular nucleus (PVN; Panicker et al. 1998). These changes in ER expression are associated with the suppression of copulatory behavior during malnutrition. In OVX rats, 48-h fasting significantly increases the number of ER $\alpha$-ir cells in the PVN, periventricular nucleus $(\mathrm{PeVN})$ and A2 region of nucleus of the solitary tract (NTS), with no appreciable alteration in the $\mathrm{VMH}, \mathrm{POA}$, and arcuate nucleus (ARC; Estacio et al. 1996a). In a similar manner, these increases in ER $\alpha$ expression could be associated with fasting-induced LH suppression. In addition, in prepubertal mice, 48-h underfeeding reduces ER-ir cells in the mPOA, VMH and ARC (Roemmich et al. 1997), which could be correlated with delayed puberty during undernutrition.

An increase in ER $\alpha$ expression by $48-\mathrm{h}$ fasting in the PVN and A2 region of the NTS (Estacio et al. 1996a), could augment the binding potential of estrogen, and therefore, might explain the estrogen-dependent suppression of LH secretion during fasting. Thus, a fasting-induced increase in ER $\alpha$ expression may play a key role in regulating LH secretion. 2-Deoxy-Dglucose (2DG)-induced glucoprivation suppresses LH release (Nagatani et al. 1996) and increases ER $\alpha$-ir cells in the PVN and NTS within $1 \mathrm{~h}$ (Reyes et al. 2001), suggesting that ER $\alpha$ 
expression could be acutely stimulated. However, unlike glucoprivation, fasting generates more complex physiological signals and takes longer to suppress LH secretion compared with 2DG-induced glucoprivation (Panicker et al. 1998). Therefore, we determined the time course of ER $\alpha$ expression in the PVN and NTS from the onset of fasting, thereby identifying more fully the mechanism underlying the fastinginduced LH suppression.

Previous studies have demonstrated noradrenergic regulation of estrogen binding in the hypothalamus (Blaustein et al. 1986, Blaustein 1987, Blaustein \& Turcotte 1987). Noradrenergic neurons arising from the lower brainstem project to the PVN (Sawchenko \& Swanson 1982, Cunningham \& Sawchenko 1988, Mezey \& Palkovits 1991). We have demonstrated that ER $\alpha$ colocalized within noradrenergic cell bodies is increased by pharmacological glucoprivation (Reyes et al. 2001). In addition, lesioning catecholaminergic inputs to the PVN 2 weeks prior to fasting and glucoprivation precluded fasting- and glucoprivation-induced increase in ER $\alpha$-ir cells in the PVN (Estacio et al. 2004). Hence, we hypothesized that during fasting ER $\alpha$ may be colocalized in the noradrenergic neurons in the A2 region of the NTS, and that noradrenergic terminals target ER $\alpha$-containing neurons in the PVN. Estrogendependent activation of this pathway during fasting could activate the brainstem and modulate the sensitivity of the PVN to the noradrenergic input and thus be part of the cascade of events that leads to LH suppression.

In the present study, we investigated the time course of ER $\alpha$ expression in specific brain areas of OVX rats during fasting and characterized the anatomical relationship of ER $\alpha$ with noradrenergic expressing neurons in the A2 region and noradrenergic fibers in the PVN.

\section{Materials and Methods}

\section{Animals and treatments}

After monitoring at least two consecutive estrous cycles, adult female Wistar-Imamichi rats (200-240 g) were individually caged in a controlled environment (14 h light: $10 \mathrm{~h}$ darkness, lights on at $0500 \mathrm{~h}$ and off at $\left.1900 \mathrm{~h}, 24 \pm 2{ }^{\circ} \mathrm{C}\right)$. They were allowed free access to food (CE-2, Clea Japan, Inc., Tokyo, Japan) and water unless otherwise indicated. Rats were OVX under ether anesthesia to eliminate endogenous estrogens. The antibody used in this study has been reported to recognize both occupied and unoccupied ER $\alpha$ (Okamura et al. 1992). However, one study using the same antibody shows a downregulation of ER $\alpha$ expression in the presence of estrogen (Okamura et al. 1994). If an increase in ER $\alpha$ expression is a key event in the enhanced LH response to fasting observed in estradiol-treated OVX rats, then this increase should occur in the presence or absence of estrogen. We chose to use the OVX rats, so that ER $\alpha$ expression would not be masked by the presence of estrogen.

\section{Fasting}

Rats were randomly assigned to groups ( $n=4$ per group) 12 days after ovariectomy and were fasted for $6,24,30$, and $48 \mathrm{~h}$, starting at $1300 \mathrm{~h}$. Feed was available for the control groups ad libitum.

\section{Immunohistochemistry}

At the end of each fasting period, rats were deeply anesthetized with pentobarbital sodium $(50 \mathrm{mg} / \mathrm{kg})$ and perfused intracardially with $0.05 \mathrm{M}$ PBS (pH 7.5) followed by ice-cold $4 \%$ formaldehyde in $0.05 \mathrm{M}$ phosphate buffer (PB). Unfasted controls were perfused at either 1300 or $1900 \mathrm{~h}$. These periods were chosen because two of the fasted groups were perfused at $1300 \mathrm{~h}$ (24- and 48-h fasting) or $1900 \mathrm{~h}$, (6- and 30-h fasting) and the feeding behavior was expected to occur around $1900 \mathrm{~h}$, which is the onset of darkness. Brains were postfixed for $2-3 \mathrm{~h}$ in the same fixative and immersed in $30 \%$ sucrose in $0.05 \mathrm{M} \mathrm{PB}$ at $4{ }^{\circ} \mathrm{C}$. Sequential $50 \mu \mathrm{m}$ coronal sections through the hypothalamus and medulla oblongata were prepared using a cryostat (Leica CM 1800, Leica, Nussloch, Germany) and stored at $-20^{\circ} \mathrm{C}$ in cryoprotectant until stained.

Every fourth and third section of the hypothalamus and medulla oblongata respectively was processed for $\mathrm{ER} \alpha$ immunostaining using the avidin-biotin complex (ABC) method that has been previously described (Reyes et al. 2001, Estacio et al. 2004). The AS 409 anti-rat ER $\alpha$ used in this study was kindly supplied by Dr Hayashi (Yokohama City University, Yokohama, Japan) and its specificity has been reported elsewhere (Okamura et al. 1992).

To determine whether ER $\alpha$-ir cells in the A2 region are colocalized in the neurons that produce norepinephrine (NA), every sixth section (three sections per animal) from unfasted and 48 -h fasted rats ( $n=4$ per group) was dual-stained with rabbit anti-rat $\mathrm{ER} \alpha$ and mouse monoclonal anti-dopamine- $\beta$ hydroxylase (DBH; Chemicon International, Temecula, CA, USA) using an indirect immunofluorescence technique that has been described previously (Reyes et al. 2001). Tissue sections were incubated in a cocktail containing anti-ER $\alpha(1: 20000)$ and anti-DBH (1:100) for 7 days at $4{ }^{\circ} \mathrm{C}$. ER $\alpha$ and $\mathrm{DBH}$ immunoreactivities were visualized using flourescein isothiocyanate-conjugated donkey anti-rabbit immunoglobulin G (IgG; 1:800; Jackson Laboratories, West Grove, PA, USA) and indocarbocyanine (Cy3)-conjugated donkey anti-mouse $\operatorname{IgG}$ (1:800, Jackson Laboratories) for $2 \mathrm{~h}$ in the dark at room temperature. The sections were mounted with FluoroGuard anti-fade reagent (Bio-Rad) and observed under a confocal laser scanning microscope (MRC 1024; Bio-Rad).

To determine the anatomical relationship between noradrenergic terminals and ER $\alpha$-expressing cells, sections containing the PVN were dual-stained with anti-ER $\alpha$ and anti-DBH using the ABC method. Sections (four sections per animal) from 48 -h fasted rats $(n=4)$ were immunostained for $\mathrm{ER} \alpha$ and DBH. Sections were incubated in a cocktail of primary antibodies (anti-rat ER $\alpha$ at 1:20 000 and mouse 
anti-DBH at $1: 100)$ for 7 days at $4{ }^{\circ} \mathrm{C}$. Following rinses with

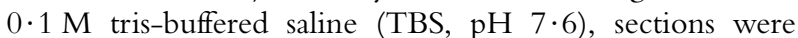
incubated with biotinylated goat anti-rabbit and biotinylated horse anti-mouse IgG (1:400; Vector Laboratories, Burlingame, CA, USA), for $1 \mathrm{~h}$. Subsequently, a 30-min incubation of $\mathrm{ABC}$ (Vector Laboratories) followed. Sections were then reacted with $0 \cdot 05 \% 3,3^{\prime}$-diaminobenzidine and $0.05 \%$ hydrogen peroxide in $0 \cdot 1 \mathrm{M}$ TBS for $\mathrm{ER} \alpha$ and $\mathrm{DBH}$ immunoreactivities. For all incubations and washes, sections were continuously agitated with a rotary shaker. DBH-ir varicosities appeared as small round structures, which were easily distinguishable from the much larger ER $\alpha$-ir cell nuclei (Fig. 3C). Then, sections were treated with 1\% osmium tetroxide (Electron Microscopy Sciences, Fort Washington, $\mathrm{PA}, \mathrm{USA}$ ) in $0 \cdot 1 \mathrm{M} \mathrm{PB}$ at $4{ }^{\circ} \mathrm{C}$ for $1.5 \mathrm{~h}$, rinsed for $10 \mathrm{~min}$ in $0 \cdot 1 \mathrm{M} \mathrm{PB}$ and dehydrated in an ascending series of ethanol. Osmicated sections were flat-embedded in Araldite on glass slides with silicon rubber (1 mm thick). The region of interest was examined with a microscope and photographs were taken.

\section{Statistical analysis}

Slides were coded to avoid bias while counting. ER $\alpha-$, DBHand dual-labeled cells were counted twice and the average was calculated. ER $\alpha$ in the medial parvocellular PVN, A2 region of the NTS, ARC, and VMH were counted following the anatomical levels (posterior from the bregma) represented in the rat brain atlas of Paxinos \& Watson (1986): PVN (2.12$1 \cdot 8 \mathrm{~mm})$, A2 $(14 \cdot 6-13 \cdot 68 \mathrm{~mm})$, ARC $(2 \cdot 12-4 \cdot 16 \mathrm{~mm})$, and VMH $(2 \cdot 12-3 \cdot 60 \mathrm{~mm})$. Since our previous studies show that the medial parvocellular PVN is the area where ER $\alpha$-ir cells are found during fasting (Estacio et al. 1996a, 1996b, 2004), counting was only conducted in this subnucleus of the PVN. Statistical significance between groups was determined by one-way ANOVA. All statistical analyses were performed using the StatView program (StatView-J 5•0, SAS Institute, Inc., Cary, NC, USA) followed by post hoc StudentNewman-Keuls multiple comparisons test. Values were considered significant when $P<0 \cdot 05$.

\section{Results}

Fasting significantly increased the number of ER $\alpha$-ir cells $(P<0 \cdot 05)$ in the PVN and NTS in OVX rats $30 \mathrm{~h}$ after its onset as compared with unfasted controls and rats fasted for 6 and $24 \mathrm{~h}$ (Fig. 1). The increased expression of ER $\alpha$-ir cells

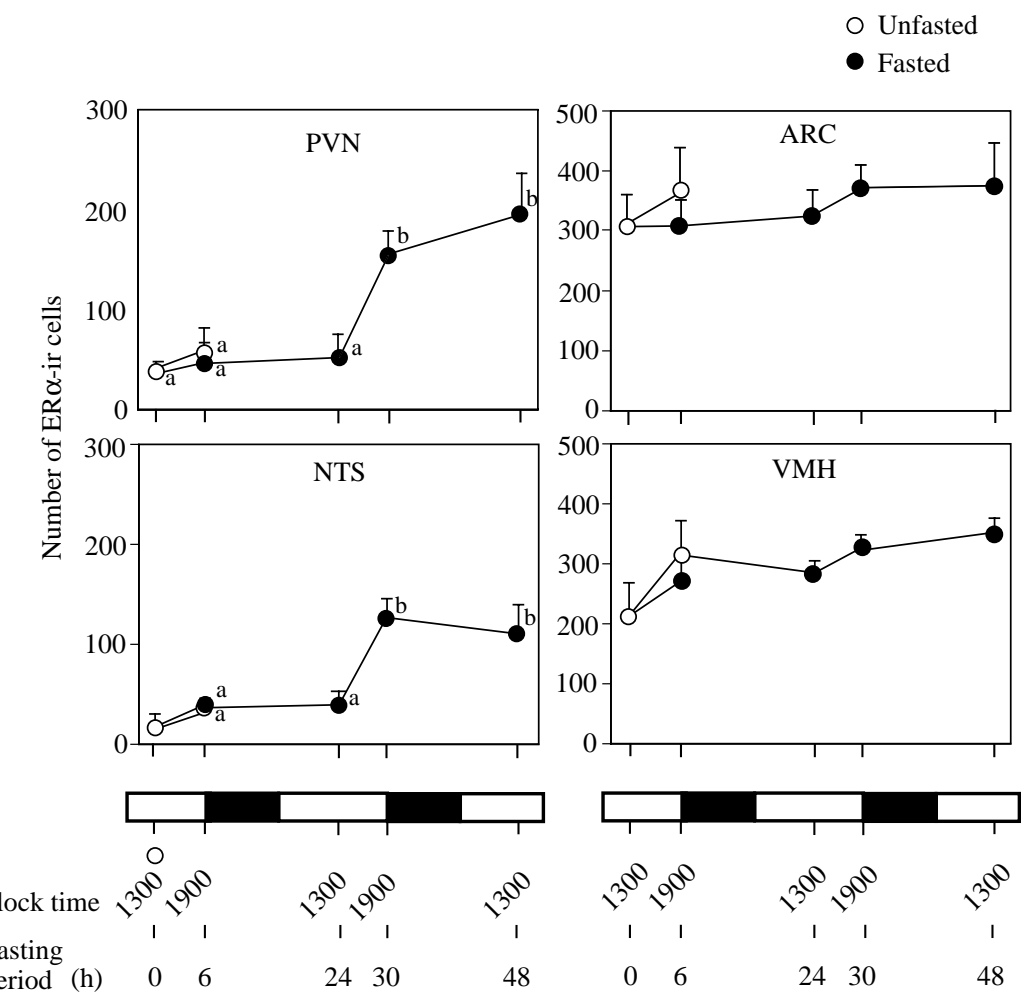

Figure 1 Effects of fasting on the number of estrogen receptor $\alpha(E R \alpha)$-immunoreactive (ir) cells in the paraventricular nucleus (PVN), periventricular nucleus (PeVN), arcuate nucleus (ARC), ventromedial hypothalamus (VMH), and nucleus of the solitary tract (NTS) in ovariectomized (OVX) rats. Values are means \pm s.E.M. Values with different letters are significantly different $(P<0 \cdot 05)$ from each other in each time point studied (Student-Newman-Keuls multiple comparisons test after ANOVA). 
$(P<0 \cdot 05)$ was sustained $48 \mathrm{~h}$ following fasting in the same nuclei compared with unfasted controls and rats fasted for 6 and $24 \mathrm{~h}$. ER $\alpha$ expression did not change significantly at any time point in the ARC and VMH (Fig. 1).

Figure 2 presents the distribution of ER $\alpha$-ir cells in the PVN (Fig. 2A-C), NTS (Fig. 2D-F), and ARC (Fig. 2G-I) of representative animals. In 30- (Fig. 2B) and 48-h (Fig. 2C)fasted rats, $E R \boldsymbol{\alpha}$-ir cells were observed in the medial parvocellular PVN with more cells in the ventral and periventricular portions compared with unfasted rats (Fig. 2A). There were many ER $\alpha$-ir cells distributed throughout the A2 region of the NTS in 30-h (Fig. 2E) and 48-h-fasted rats (Fig. 2F) compared with unfasted rats (Fig. 2D). A large number of ER $\alpha$-ir cells were found in the ARC, but there was no difference in the distribution or number of rats that were fasted (Fig. 2H-I) or unfasted (Fig. 2G).

The numbers of ir neurons for $\mathrm{ER} \alpha, \mathrm{DBH}$, and duallabeled cells in the A2 region of the NTS are presented in Table 1. Immunofluorescence labeling for ER $\alpha$ and DBH was visualized through the A2 region of the NTS. Immunolabeling showed DBH-ir neurons in the A2 region of the NTS of both unfasted and 48-h fasted rats. The number of DBH-ir

\section{Unfast}
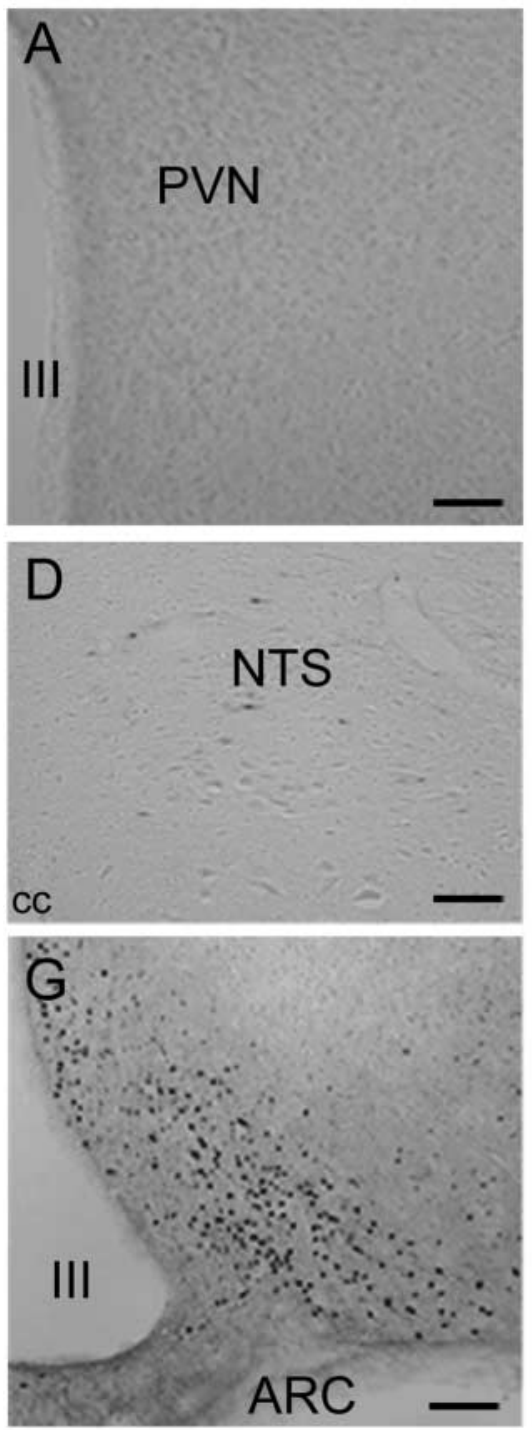

30-h fast
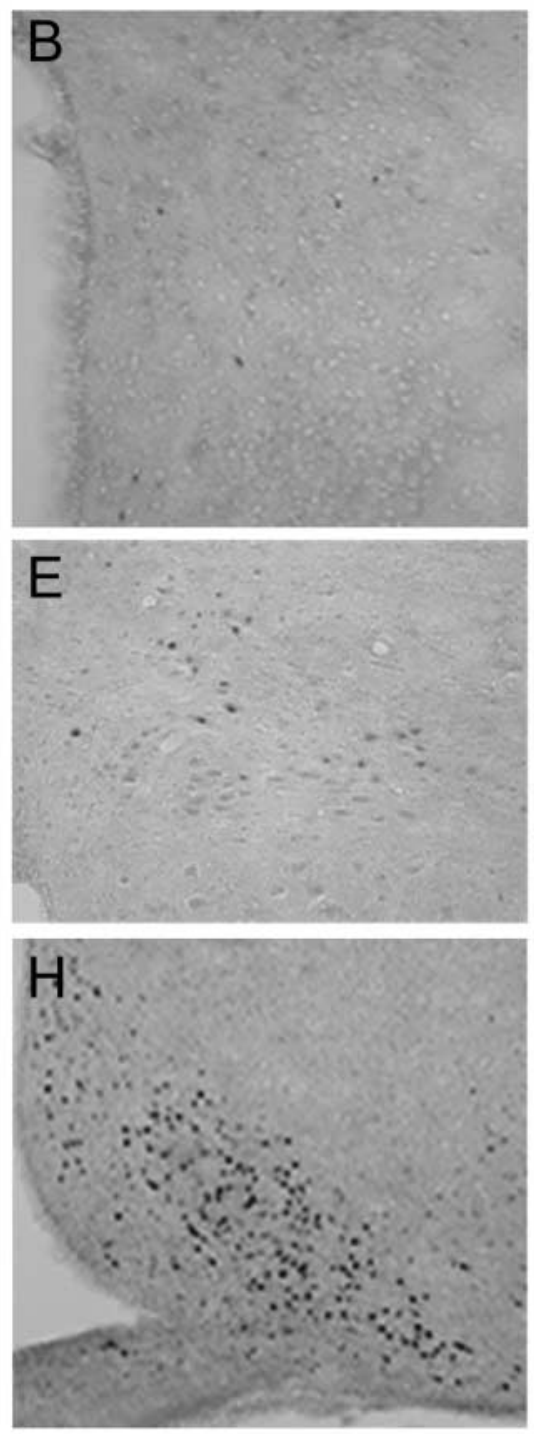

48-h fast
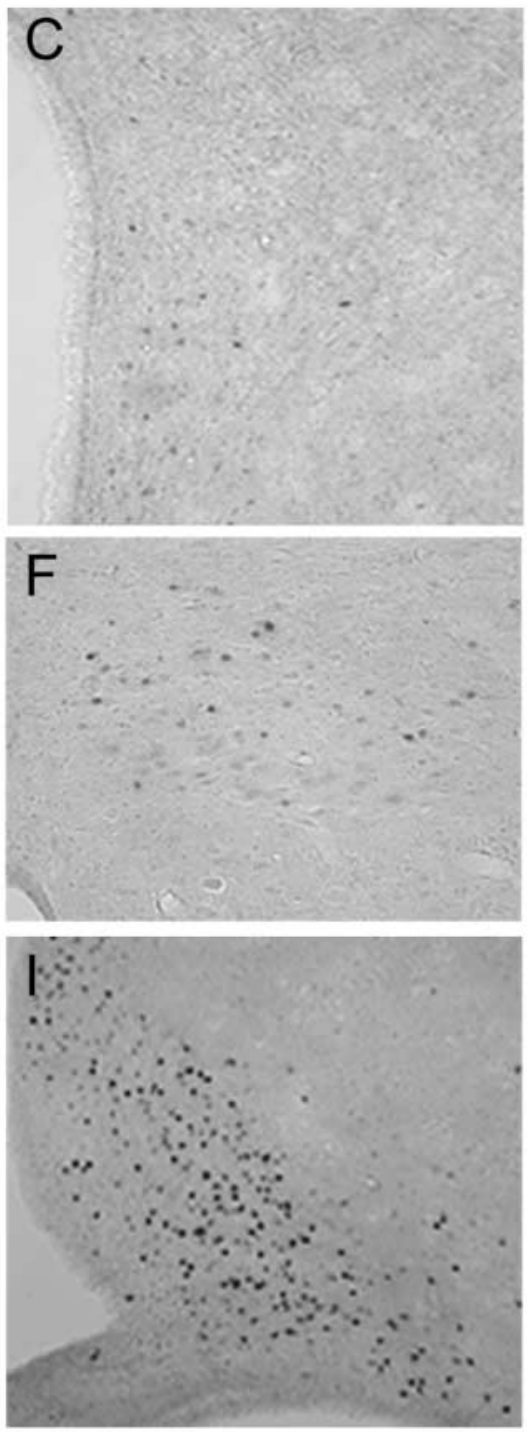

Figure 2 Estrogen receptor $\alpha(E R \alpha)$-immunoreactive (ir) cells in the PVN (A-C), NTS (D-F), and ARC (G-l) in OVX rats. ER $\alpha$-ir cells in the PVN, NTS, and ARC in OVX rats fasted for $30 \mathrm{~h}(\mathrm{~B}, \mathrm{E}, \mathrm{H})$ and $48 \mathrm{~h}(\mathrm{C}, \mathrm{F}, \mathrm{I})$ respectively. Note the absence of, or few, ER $\alpha$-ir cells in the PVN (A) and NTS (D) in unfasted OVX rats. Also, there was no difference in the distribution and number of ER $\alpha$-ir cells in the ARC (G-I). III, third ventricle; cc, central canal. Scale bar $=100 \mu \mathrm{m}$. 
Table 1 Number of estrogen receptor $\alpha(E R \alpha)$, dopamine- $\beta$-hydroxylase (DBH), and dual-labeled cells in the nucleus of the solitary tract of 48 -h fasted and unfasted ovariectomized rats $(n=4)$

\begin{tabular}{|c|c|c|c|c|}
\hline & $E R \alpha$ & DBH & $\mathrm{ER} \alpha+\mathrm{DBH}$ & $\begin{array}{l}\text { Double-labeled cells } \\
\text { (percent of DBH) }\end{array}$ \\
\hline \multicolumn{5}{|l|}{ Group } \\
\hline Unfast & $8 \cdot 25 \pm 4 \cdot 92^{b}$ & $73 \cdot 50 \pm 8 \cdot 22$ & $6 \cdot 00 \pm 3 \cdot 24^{b}$ & $8 \cdot 16^{b}$ \\
\hline 48-h fast & $40 \cdot 00 \pm 6 \cdot 75^{a}$ & $63 \cdot 38 \pm 13 \cdot 39$ & $29 \cdot 63 \pm 5 \cdot 81^{a}$ & $46 \cdot 75^{a}$ \\
\hline
\end{tabular}

Superscripts with different letters indicate statistical significance.

neurons were not altered by fasting, however, more DBH-ir neurons expressed ER $\alpha$ after $48-\mathrm{h}$ fasting compared with unfasted rats $(P<0 \cdot 05$, Table 1 and Fig. 3A-B). In 48-hfasted rats, $46 \cdot 75 \%$ DBH-ir cells also expressed ER $\alpha$. This percentage was significantly higher than in corresponding unfasted controls (only $8 \cdot 16 \%$ DBH-ir cells expressed ER $\alpha$ ).

Our dual-immunocytochemical studies of the PVN revealed that DBH-ir varicosities, appearing as punctuate structures, were found throughout the PVN in 48-h-fasted rats. Figure $3 \mathrm{C}$ shows the juxtaposition of ER $\alpha$-ir neurons and DBH-ir varicosities in the PVN.

\section{Discussion}

Our present findings show that fasting induced ER $\alpha$ in the PVN and NTS in OVX rats $30 \mathrm{~h}$ after its onset compared with unfasted rats. The significant increase in ER $\alpha$ expression was sustained until at least $48 \mathrm{~h}$. Additionally, ER $\alpha$ and $\mathrm{DBH}$ are colocalized in the A2 region of the NTS, with more $\mathrm{DBH}-\mathrm{ir}$ neurons expressing ER $\alpha$ after $48-\mathrm{h}$ fasting. Our results also provide the first anatomical evidence that in the PVN, ER $\alpha$-ir neurons are juxtaposed with DBH-ir varicosities.

Using immunoblot analysis, the characterization and specificity of the rabbit antiserum against rat ER $\alpha$ used in the present study have been previously described (Okamura et al. 1992). Specifically, immunocytochemistry recognizes $\mathrm{ER} \alpha$ in the pituitary and neurons in specific brain regions (Okamura et al. 1992, 1994). While it is known that ER $\beta$ immunoreactivity is expressed in the PVN and the NTS (Simonian \& Herbison 1997, Shughrue et al. 1997), our previous reports have shown that 48 -h fasting significantly increases ER $\alpha$ expression in these nuclei (Estacio et al. 1996a, 1996b, Maeda et al. 1996, Estacio et al. 2004). To our knowledge, whether ER $\beta$ expression is increased during fasting has not been elucidated. Thus, the possibility of crossimmunoreactivity between $\operatorname{ER} \alpha$ and $\operatorname{ER} \beta$ during 30- and 48-h fasting in the PVN and the A2 regions of the NTS requires further investigation. $\operatorname{ER} \beta$ has a specific binding affinity for estradiol and is capable of activating the estrogenresponse element reporter gene construct (Kuiper et al. 1996). Hence, ER $\beta$ has been instrumental in understanding how estrogen exerts its myriad of physiological, sometimes opposing effects (Nillson et al. 2001). In fact, Imamov and colleagues (2005), using ventral prostate epithelium in mice at various postnatal periods, described the opposing actions of $E R \alpha$ and ER $\beta$ on epithelial proliferation and differentiation in a Yin-Yang paradigm. Using the present fasting model, it would be interesting to determine if $\operatorname{ER} \beta$ mediates estrogenic signals in the PVN and the NTS that would describe the existence of the Yin-Yang paradigm or the opposing actions of $\operatorname{ER} \alpha$ and $\operatorname{ER} \beta$. Further studies are needed to address this issue.

Temporal ER $\alpha$ expression in the PVN and the NTS was evident $30 \mathrm{~h}$ after fasting and sustained until at least $48 \mathrm{~h}$, confirming our previous observations that fasting for $48 \mathrm{~h}$ induces $\mathrm{ER} \alpha$ expression in the same nuclei (Estacio et al. 1996a, Maeda et al. 1996). Similarly, 2DG-induced glucoprivation increases ER $\alpha$ expression in the same nuclei within an hour (Reyes et al. 2001). These data suggest that $\mathrm{ER} \alpha$ expression in the PVN and A2 region of the NTS may play a role in enhancing the suppressive effect of fasting or glucoprivation on $\mathrm{LH}$ secretion. It has been demonstrated that estrogen induces $c$-fos expression in the A2 region of the NTS (Jennes et al. 1992) and upregulates receptor gene expression in the hypothalamus (Blaustein \& Turcotte 1989, Shughrue et al. 1997) and A2 region (Haywood et al. 1999). Thus, increased ER $\alpha$ expression at 30-h fasting, which was sustained until at least 48-h fasting, may influence transcriptional gene expression that would direct the sequence of events culminating in intensified $\mathrm{LH}$ suppression by 48-h fasting.

OVX female rats were used over intact or estradiol-treated female rats for the purpose of eliminating the circulating endogenous estrogen. Although the rabbit anti-rat ER $\alpha$ used in this study recognizes both occupied and unoccupied ER $\alpha$ (Okamura et al. 1992), previous investigations using immunohistochemistry showed a suppressive effect of estrogen on ER expression (Okamura et al. 1994). Therefore, if $E R \alpha$ expression heralds the suppression of $\mathrm{LH}$ secretion in response to fasting (Maeda et al. 1996, Estacio et al. 1996a) observed in intact (Cagampang et al. 1990) and estradioltreated rats (Cagampang et al. 1991, Maeda et al. 1996), there would be an increase in ER $\alpha$ expression in the presence or absence of estrogen. Using intact or estradiol-treated rats would certainly mask the ER $\alpha$ expression.

In the present study, the increased ER $\alpha$ expression and colocalization of $\mathrm{ER} \alpha$ in $\mathrm{DBH}$-ir neurons in the $\mathrm{A} 2$ region of the NTS in fasted rats suggest that the fasting signal 

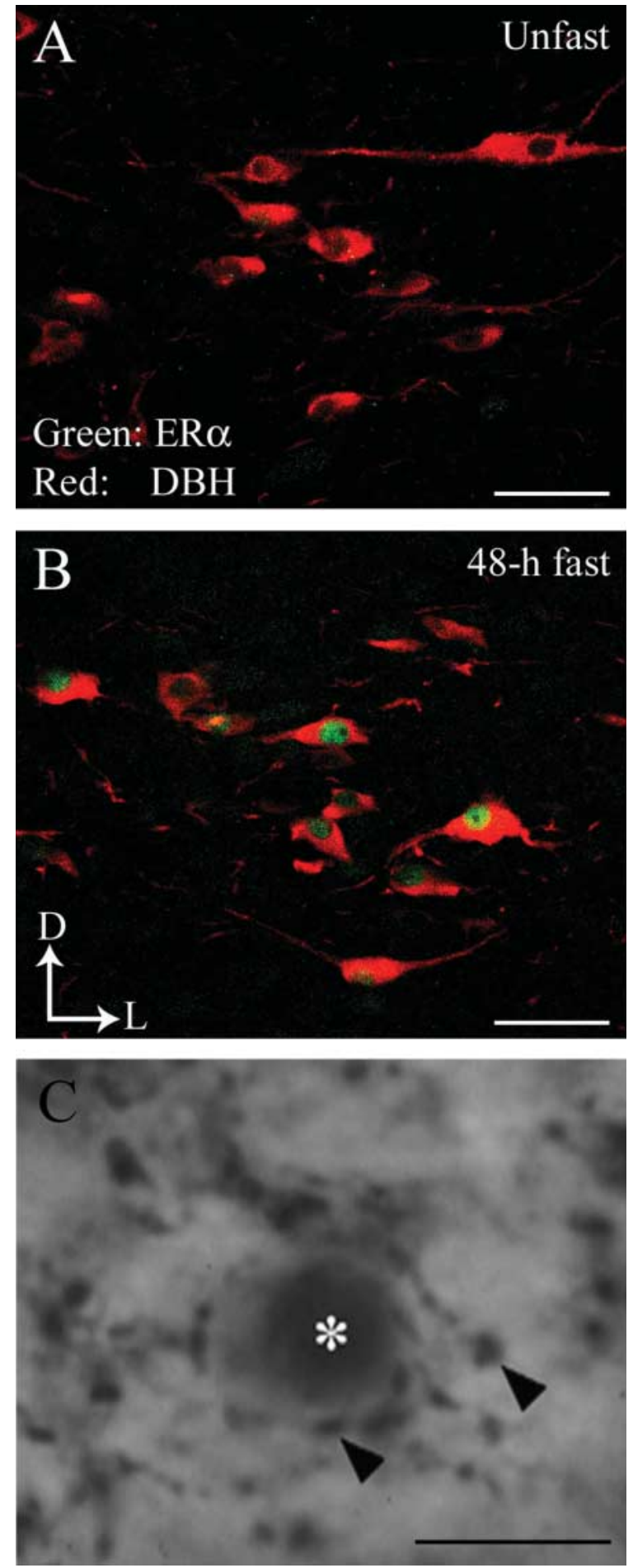

Figure 3 ( $\mathrm{A}$ and $\mathrm{B}$ ) Estrogen receptor $\alpha(\mathrm{ER} \alpha)$ and dopamine- $\beta$ hydroxylase $(\mathrm{DBH})$-immunoreactivities in the $\mathrm{A} 2$ region in the nucleus of the solitary tract in OVX rats. ER $\alpha$ (green) is colocalized within DBH-ir cells (red) in 48-h fasted rats. Arrows indicate dorsal (D) and lateral (L) orientation of the sections illustrated. Scale bar $=50 \mu \mathrm{m}$. (C) $\mathrm{DBH}$-ir varicosities (arrowheads) juxtaposed with estrogen receptor $\alpha$-ir soma (asterisks) in the PVN in OVX rats. Scale bar $=375 \mu \mathrm{m}$. stimulates $\mathrm{ER} \alpha$ expression in the $\mathrm{A} 2$ region and this may enhance the activation of A2 noradrenergic neurons projecting to the PVN during fasting. Estrogen activation of brainstem noradrenergic neurons (Jennes et al. 1992) and an increment in hypothalamic NA turnover in response to estrogen treatment is well established (Honma \& Wuttke 1980, Wise et al. 1981, Demling et al. 1985, Liaw et al. 1992). Therefore, increase in ER $\alpha$ colocalized within the noradrenergic neurons of the A2 region during fasting suggests that estrogen could increase the activation of A2 noradrenergic neurons, thereby increasing NA transmission from the A2 region to the PVN and enhancing the suppression of LH secretion. Previously, we have illustrated that complete vagotomy restored the fasting-induced $\mathrm{LH}$ suppression (Cagampang et al. 1992a) and blocked the fastinginduced increase in ER $\alpha$-ir cells in the PVN and A2 region (Estacio et al. 1996b). These results suggest that the afferent vagal nerve from the upper digestive tract transmits the fasting signal to the NTS, thereby mediating increased ER $\alpha$ expression in the PVN and A2 region.

We have demonstrated for the first time that noradrenergic varicosities in the PVN are in a close anatomical relationship with ER $\alpha$-expressing cells in the rat. Anatomically, the PVN is densely innervated by NA cell bodies originating from the A1, A2, and A6 of the lower brainstem (Sawchenko \& Swanson 1982, Cunningham \& Sawchenko 1988, Mezey \& Palkovits 1991). NA release is elevated in the PVN during fasting (Stanley et al. 1989). Moreover, the catecholaminergic regulation of estrogen binding in the hypothalamus has been illustrated (Blaustein et al. 1986, Blaustein 1987, Blaustein \& Turcotte 1987). For example, the administration of $\alpha 1$ noradrenergic antagonists decreases estrogen binding in female rat hypothalamus. In addition, an interaction between the NA system and $[3 \mathrm{H}]$ estradiol-labeled cells have been previously reported (Heritage et al. 1977). Recently, we have demonstrated that lesioning catecholaminergic inputs to the PVN by bilateral injection of saporin-conjugated anti-DBH into the PVN 2 weeks prior to fasting and glucoprivation precluded fasting- and glucoprivation-induced increase in ER $\alpha$-ir cells in the PVN (Estacio et al. 2004). Therefore, our present findings support the hypothesis that $\mathrm{A} 2$ noradrenergic neurons may directly influence ER $\alpha$ expression in the PVN during fasting.

Estrogen enhances LH suppression induced by microinjection of NA in the PVN (Tsukamura et al. 1994). The existence of noradrenergic synapses on corticotropin-releasing hormone $(\mathrm{CRH})$-containing neurons in the PVN has been demonstrated (Liposits et al. 1986) and this noradrenergic system facilitates synthesis and/or secretion of CRH both in vivo (Itoi et al. 1994) and in vitro (Tsagarakis et al. 1988). Furthermore, noradrenergic input to the PVN induces CRH release via the activation of the $\alpha$-adrenergic receptors (Cagampang et al. 1992b, Maeda et al. 1994). Anatomical studies showed that PVN neurons project to the median eminence (Armstrong \& Hatton 1980, Reyes et al. 2005). Since anti-CRH administered into the third ventricle reverses 
fasting-induced LH suppression (Tsukamura et al. 1994), $\mathrm{CRH}$ neurons in the PVN could act at the median eminence and/or POA to inhibit gonadotropin-releasing hormone, which subsequently suppresses LH secretion (Maeda \& Tsukamura 1996). The identity of the ER $\alpha$-ir cells within the PVN has yet to be established, but it is tempting to speculate that the increment in ER $\alpha$-ir cells in the PVN and A2 region of the NTS causes an increase in the sensitivity of the CRH-releasing system to the incoming NA signal during fasting and thereby suppresses LH release. Nevertheless, future studies would be useful to identify the neurochemical nature of ER $\alpha$-containing cells expressed in the PVN during fasting.

Recently, human brain tissue sections obtained from autopsy specimens of patients having suffered from major depression/major depressive disorder or bipolar disorder demonstrated a colocalization of $\mathrm{CRH}$ and $\mathrm{ER} \alpha$ in the PVN (Bao et al. 2005). Impaired appetite is one of the common features of depressed or bipolar individuals (Diagnostic and Statistical Manual IV 1994, Sugahara et al. 2004, Kawa et al. 2005, Kishi \& Elmquist 2005). However, a reduced appetite is observed in most depressive patients, while an increase in appetite is seen in fewer patients (Diagnostic and Statistical Manual IV 1994). Together with the present results, it is possible that the increased ER $\alpha$ expression in the present experimental fasting model could somehow serve as a cellular substrate related to the impairment of appetite observed in depressed patients. This is an interesting concern for further investigation.

In conclusion, our present study provides evidence that fasting induces ER $\alpha$ expression in the PVN, PeVN, and NTS $30 \mathrm{~h}$ from its onset, which is sustained until at least $48 \mathrm{~h}$. These results suggest that fasting creates complex physiological signals, some of which slowly culminate in suppression of LH secretion. Colocalization of ER $\alpha$ within the noradrenergic neurons in the A2 region, suggests a role for estrogen during fasting in increasing activation of the A2 noradrenergic neurons that project to the PVN. Moreover, the anatomical relationship of $\mathrm{DBH}$-ir varicosities and ER $\alpha$ ir cells in the PVN suggests that fasting enhances the sensitivity of the PVN to this noradrenergic signal, consequently leading to the suppression of $\mathrm{LH}$ secretion.

\section{Acknowledgements}

We would like to express our sincere gratitude to Dr Shinji Hayashi for the antibody and Dr Yoshihisa Uenoyama for his technical advice. We are also indebted to Ms Yoko Niwa and Kyoko Ohmiya for their technical assistance. This work was supported in part by Grants-in-Aid (Nos 10460131 and 11660283) from the Ministry of Education, Science, Sports and Culture of Japan; the Japan Society for the Promotion of Science (fellowship to H I). The authors declare that there is no conflict of interest that would prejudice the impartiality of this scientific work.

\section{References}

Armstrong WE \& Hatton GI 1980 The localization of projection neurons in the rat hypothalamic paraventricular nucleus following vascular and neurohypophysial injections of HRP. Brain Research Bulletin 5 473-477.

Bao AM, Hestiantoro A, Van Someren EJ, Swaab DF \& Zhou JN 2005 Colocalization of corticotrophin-releasing hormone and estrogen receptoralpha in the paraventricular nucleus of the hypothalamus in Mood disorders. Brain 128 1301-1313.

Blaustein JD 1987 The alpha 1-noradrenergic antagonist prazosin decreases the concentration of estrogen receptors in female rat hypothalamus. Brain Research 404 39-50.

Blaustein JD \& Turcotte J 1987 Further evidence of noradrenergic regulation of rat hypothalamic estrogen receptor concentration: possible nonfunctional increase and functional decrease. Brain Research 436 253-264.

Blaustein JD \& Turcotte JC 1989 Estradiol-induced progestin receptor immunoreactivity is found only in estrogen receptor-immunoreactive cells in guinea pig brain. Neuroendocrinology 49 454-461.

Blaustein JD, Brown TJ \& Swearengen ES 1986 Dopamine-beta-hydroxylase inhibitors modulate the concentration of functional estrogen receptors in female rat hypothalamus and pituitary gland. Neuroendocrinology $\mathbf{4 3}$ 150-158.

Bronson FH 1989 Mammalian Reproductive Physiology., Chicago: University of Chicago Press.

Cagampang FR, Maeda K, Yokoyama A \& Ota K 1990 Effect of food deprivation on the pulsatile LH release in the cycling and ovariectomized female rat. Hormone and Metabolic Research 22 269-272.

Cagampang FR, Maeda KI, Tsukamura H, Ohkura S \& Ota K 1991 Involvement of ovarian steroids and endogenous opioids in the fastinginduced suppression of pulsatile LH release in ovariectomized rats. Journal of Endocrinology 129 321-328.

Cagampang FR, Maeda K \& Ota K 1992a Involvement of the gastric vagal nerve in the suppression of pulsatile luteinizing hormone release during acute fasting in rats. Endocrinology 130 3003-3006.

Cagampang FR, Ohkura S, Tsukamura H, Coen CW, Ota K \& Maeda K $1992 b$ Alpha 2-adrenergic receptors are involved in the suppression of luteinizing hormone release during acute fasting in the ovariectomized estradiol-primed rats. Neuroendocrinology 56 724-728.

Cunningham ET Jr \& Sawchenko PE 1988 Anatomical specificity of noradrenergic inputs to the paraventricular and supraoptic nuclei of the rat hypothalamus. Journal of Comparative Neurology 274 60-76.

Demling J, Fuchs E, Baumert M \& Wuttke W 1985 Preoptic catecholamine, GABA, and glutamate release in ovariectomized and ovariectomized estrogen-primed rats utilizing a push-pull cannula technique. Neuroendocrinology 41 212-218.

Diagnostic and Statistical Manual IV 1994 American Psychiatric Association, Washington DC.

Estacio MAC, Yamada S, Tsukamura H, Hirunagi K \& Maeda K 1996a Effect of fasting and immobilization stress on estrogen receptor immunoreactivity in the brain in ovariectomized female rats. Brain Research 717 55-61.

Estacio MAC, Tsukamura H, Yamada S, Tsukahara S, Hirunagi K \& Maeda K $1996 b$ Vagus nerve mediates the increase in estrogen receptors in the hypothalamic paraventricular nucleus and nucleus of the solitary tract during fasting in ovariectomized rats. Neuroscience Letters 208 25-28.

Estacio MAC, Tsukamura H, Reyes BAS, Uenoyama Y, I'Anson H \& Maeda K-I 2004 Involvement of brainstem catecholaminergic inputs to the hypothalamic paraventricular nucleus in estrogen receptor $\alpha$ expression in this nucleus during different stress conditions in female rats. Endocrinology 145 4917-4926.

Goodman RL, Legan SJ, Ryan KD, Foster DL \& Karsch FJ 1981 Importance of variations in behavioural and feedback actions of oestradiol to the control of seasonal breeding in the ewe. Journal of Endocrinology 89 229-240.

Haywood SA, Simonian SX, van der Beek EM, Bicknell RJ \& Herbison AE 1999 Fluctuating estrogen and progesterone receptor expression in brainstem norepinephrine neurons through the rat estrous cycle. Endocrinology 140 3255-3263. 
Heritage AS, Grant LD \& Stumpf WE 1977 3H estradiol in catecholamine neurons of rat brain stem: combined localization by autoradiography and formaldehyde-induced fluorescence. Journal of Comparative Neurology 176 607-630.

Honma K \& Wuttke W 1980 Norepinephrine and dopamine turnover rates in the medial preoptic area and the mediobasal hypothalamus of the rat brain after various endocrinological manipulations. Endocrinology 106 1848-1853.

Imamov O, Shim GJ, Warner M \& Gustafsson JA 2005 Estrogen receptor beta in health and disease. Biology of Reproduction 73 866-871.

Itoi K, Suda T, Tozawa F, Dobashi I, Ohmori N, Sakai Y, Abe K \& Demura H 1994 Microinjection of norepinephrine into the paraventricular nucleus of the hypothalamus stimulates corticotropin-releasing factor gene expression in conscious rats. Endocrinology 135 2177-2182.

Jennes L, Jennes ME, Purvis C \& Nees M 1992 c-fos expression in noradrenergic A2 neurons of the rat during the estrous cycle and after steroid hormone treatments. Brain Research 586 171-175.

Kawa I, Carter JD, Joyce PR, Doughty CJ, Frampton CM, Wells JE, Walsh AE \& Olds RJ 2005 Gender differences in bipolar disorder: age of onset, course, comorbidity, and symptom presentation. Bipolar Disorders 7 119-125.

Kishi T \& Elmquist JK 2005 Body weight is regulated by the brain: a link between feeding and emotion. Molecular Psychiatry 10 132-146.

Kuiper GG, Enmark E, Pelto-Huikko M, Nilsson S \& Gustafsson JA 1996 Cloning of a novel receptor expressed in rat prostate and ovary. PNAS $\mathbf{9 3}$ 5925-5930.

Li HY, Wade GN \& Blaustein JD 1994 Manipulations of metabolic fuel availability alter estrous behavior and neural estrogen receptor immunoreactivity in Syrian hamsters. Endocrinology 135 240-247.

Liaw JJ, He JR, Hartman RD \& Barraclough CA 1992 Changes in tyrosine hydroxylase mRNA levels in medullary A1 and A2 neurons and locus coeruleus following castration and estrogen replacement in rats. Brain Research. Molecular Brain Research 13 231-238.

Liposits Z, Phelix C \& Paull WK 1986 Electron microscopic analysis of tyrosine hydroxylase, dopamine-beta-hydroxylase and phenylethanolamine- $N$-methyltransferase immunoreactive innervation of the hypothalamic paraventricular nucleus in the rat. Histochemistry 84 105-120.

Maeda K \& Tsukamura H 1996 Neuroendocrine mechanism mediating fasting-induced suppression of luteinizing hormone secretion in female rats. Acta Neurobiologiae Experimentalis (Wars) 56 787-796.

Maeda K, Cagampang FR, Coen CW \& Tsukamura H 1994 Involvement of the catecholaminergic input to the paraventricular nucleus and of corticotropin-releasing hormone in the fasting-induced suppression of luteinizing hormone release in female rats. Endocrinology 134 1718-1722.

Maeda K, Nagatani S, Estacio MA \& Tsukamura H 1996 Novel estrogen feedback sites associated with stress-induced suppression of luteinizing hormone secretion in female rats. Cellular and Molecular Neurobiology 16 311-324.

Mezey E \& Palkovits M 1991 CRF-containing neurons in the hypothalamic paraventricular nucleus: regulation, especially by catecholamines. Frontiers in Neuroendocrinology 12 23-37.

Nagatani S, Bucholtz DC, Murahashi K, Estacio MA, Tsukamura H, Foster DL \& Maeda KI 1996 Reduction of glucose availability suppresses pulsatile luteinizing hormone release in female and male rats. Endocrinology 137 $1166-1170$.

Nilsson S, Makela S, Treuter E, Tujague M, Thomsen J, Andersson G, Enmark E, Pettersson K, Warner M \& Gustafsson JA 2001 Mechanisms of estrogen action. Physiological Reviews 81 1535-1565.

Okamura H, Yamamoto K, Hayashi S, Kuroiwa A \& Muramatsu M 1992 A polyclonal antibody to the rat oestrogen receptor expressed in Escherichia coli: characterization and application to immunohistochemistry. Journal of Endocrinology 135 333-341.
Okamura H, Yokosuka M \& Hayashi S 1994 Induction of substance P-immunoreactivity by estrogen in neurons containing estrogen receptors in the anteroventral periventricular nucleus of female but not male rats. Journal of Neuroendocrinology 6 609-615.

Panicker AK, Mangels RA, Powers JB, Wade GN \& Schneider JE 1998 AP lesions block suppression of estrous behavior, but not estrous cyclicity, in food-deprived Syrian hamsters. American Journal of Physiology 275 R158-R164.

Paxinos G \& Watson C 1986 The Rat Brain in Stereotaxic Coordinates, New York: Academic Press.

Reyes BAS, Estacio MA, I'Anson H, Tsukamura H \& Maeda K-I 2001 Glucoprivation increases estrogen receptor immunoreactivity in the brain catecholaminergic neurons in ovariectomized rats. Neuroscience Letters 299 109-112.

Reyes BAS, Valentino RJ, Xu G \& Van Bockstaele EJ 2005 Hypothalamic projections to locus coeruleus neurons in rat brain. European Journal of Neuroscience 22 93-106.

Roemmich JN, Li X, Rogol AD \& Rissman EF 1997 Food availability affects neural estrogen receptor immunoreactivity in prepubertal mice. Endocrinology 138 5366-5373.

Sawchenko PE \& Swanson LW 1982 The organization of noradrenergic pathways from the brainstem to the paraventricular and supraoptic nuclei in the rat. Brain Research 257 275-325.

Shughrue PJ, Lane MV \& Merchenthaler I 1997 Regulation of progesterone receptor messenger ribonucleic acid in the rat medial preoptic nucleus by estrogenic and antiestrogenic compounds: an in situ hybridization study. Endocrinology 138 5476-5484.

Simonian SX \& Herbison AE 1997 Differential expression of estrogen receptor alpha and beta immunoreactivity by oxytocin neurons of rat paraventricular nucleus. Journal of Neuroendocrinology 9 803-806.

Stanley BG, Schwartz DH, Hernandez L, Hoebel BG \& Leibowitz SF 1989 Patterns of extracellular norepinephrine in the paraventricular hypothalamus: relationship to circadian rhythm and deprivation-induced eating behavior. Life Science 45 275-282.

Sugahara H, Akamine M, Kondo T, Fujisawa K, Yoshimasu K, Tokunaga S \& Kudo C 2004 Somatic symptoms most often associated with depression in an urban hospital medical setting in Japan. Psychiatry Research 128 305-311.

Tsagarakis S, Holly JM, Rees LH, Besser GM \& Grossman A 1988 Acetylcholine and norepinephrine stimulate the release of corticotropinreleasing factor-41 from the rat hypothalamus in vitro. Endocrinology 123 1962-1969.

Tsukamura H, Nagatani S, Cagampang FR, Kawakami S \& Maeda K 1994 Corticotropin-releasing hormone mediates suppression of pulsatile luteinizing hormone secretion induced by activation of alpha-adrenergic receptors in the paraventricular nucleus in female rats. Endocrinology $\mathbf{1 3 4}$ 1460-1466.

Wise PM, Rance N \& Barraclough CA 1981 Effects of estradiol and progesterone on catecholamine turnover rates in discrete hypothalamic regions in ovariectomized rats. Endocrinology 108 2186-2193.

Received 11 April 2006

Received in final form 22 May 2006

Accepted 6 June 2006 